\begin{tabular}{|r|}
\hline ANGIES \\
NEW PERSPECTIUE5 \\
ANGLOPHINE WTRLD \\
\hline
\end{tabular}

\title{
Angles
}

New Perspectives on the Anglophone World

\author{
6 | 2018 \\ Experimental Art
}

\section{In the Turbine of Experimentation: Tate Modern and the New (?) Rationale of Collective Performance}

\section{Catherine Bernard}

\section{(2) OpenEdition}

Journals

Electronic version

URL: https://journals.openedition.org/angles/1024

DOI: 10.4000/angles. 1024

ISSN: 2274-2042

Publisher

Société des Anglicistes de l'Enseignement Supérieur

\section{Electronic reference}

Catherine Bernard, "In the Turbine of Experimentation: Tate Modern and the New (?) Rationale of Collective Performance", Angles [Online], 6 | 2018, Online since 01 April 2018, connection on 06 June 2022. URL: http://journals.openedition.org/angles/1024 ; DOI: https://doi.org/10.4000/angles. 1024

This text was automatically generated on 6 June 2022 .

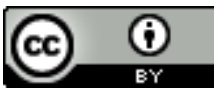

Angles est mise à disposition selon les termes de la Licence Creative Commons Attribution 4.0 International. 


\title{
In the Turbine of Experimentation: Tate Modern and the New (?) Rationale of Collective Performance
}

\author{
Catherine Bernard
}

1 Like many artistic categories, the "experimental" has undergone many mutations. It occupies an in-between theoretical space in which sciences, philosophy - specifically empiricism - as well as the arts - in their modernist and avant-garde instantiations cohabit. Artistic experimentation has consequently remained an evasive phenomenon that resists definition. Vincent Broqua chooses to define artistic experimentation as a form of conceptual "constellation" ("étoilement" in French):

Rather than seeing it as if under erasure, and drawing from the way Barthes explores Sarrasine through its figures, I would like to envisage the experimental as a constellation. Since, as Barthes himself suggests, it is not compact as an argument might be, the constellation leaves the notion open, while allowing for synthesis and analysis. ${ }^{1}$ (Broqua 2013: 27, my translation)

As modern art morphed into contemporary art, the notion has become more evasive than ever. The "end of art," as defined by Arthur Danto, is supposed to have brought the very narrative of artistic experimentation to a close (Danto 1997). Artistic pluralism has replaced the modern dialectics holding mainstream art and experimental art in fruitful tension (Danto 1992: 217-231). If art is no longer driven by a quest for "truth," whether it be in the form of truth to the object, of medium specificity or of truth to emotion, then the dialectics opposing mainstream and experimentation loses some of its centrality. As I hope to show in the argument that follows, artistic pluralism has indeed unhinged the definition of experimentation inherited from modernism and from the avant-garde and has consequently also made it increasingly difficult to circumscribe what is meant by artistic experimentation. 


\section{Experimenting (with) modernity}

3 For that very reason, it might be useful to place the recent avatars of experimentation in a broader and longer history. If we retain one of the accepted definitions of artistic experimentation, as rehearsed by Terry Smith in Volume 08 of Studies in Material Thinking, published in 2012, the notion should not be tethered to the $20^{\text {th }}$ century and to modern art, nor even to a longer history of art going back to Romantic art and its urge to push back the limits of representation. Experimentation in art in fact looks back to modernity and its foregrounding of epistemology and enlightnement as exemplified, for instance, by Joseph Wright of Derby's oil, An Experiment on a Bird in an Air Pump, of 1768 (Figure 1): “Wright's painting not only depicts an experiment taking place, it also, and more importantly, pictures the quintessentially modern idea of experimentality as such." (Smith 2012: 1). Smith concurrently emphasizes the allegorical nature of Wright's vision and the way the chiaroscuro - the work's formal language - draws on the long tradition of "religious paintings of miraculous revelation - including, to be specific, the moment of holy judgment over the fate of the living. He has, of course, substituted a scientific demonstration, making his painting an awe-struck celebration of Enlightenment rationalism." (2)

Figure 1: Joseph Wright of Derby, An Experiment on a Bird in an Air Pump, 1768

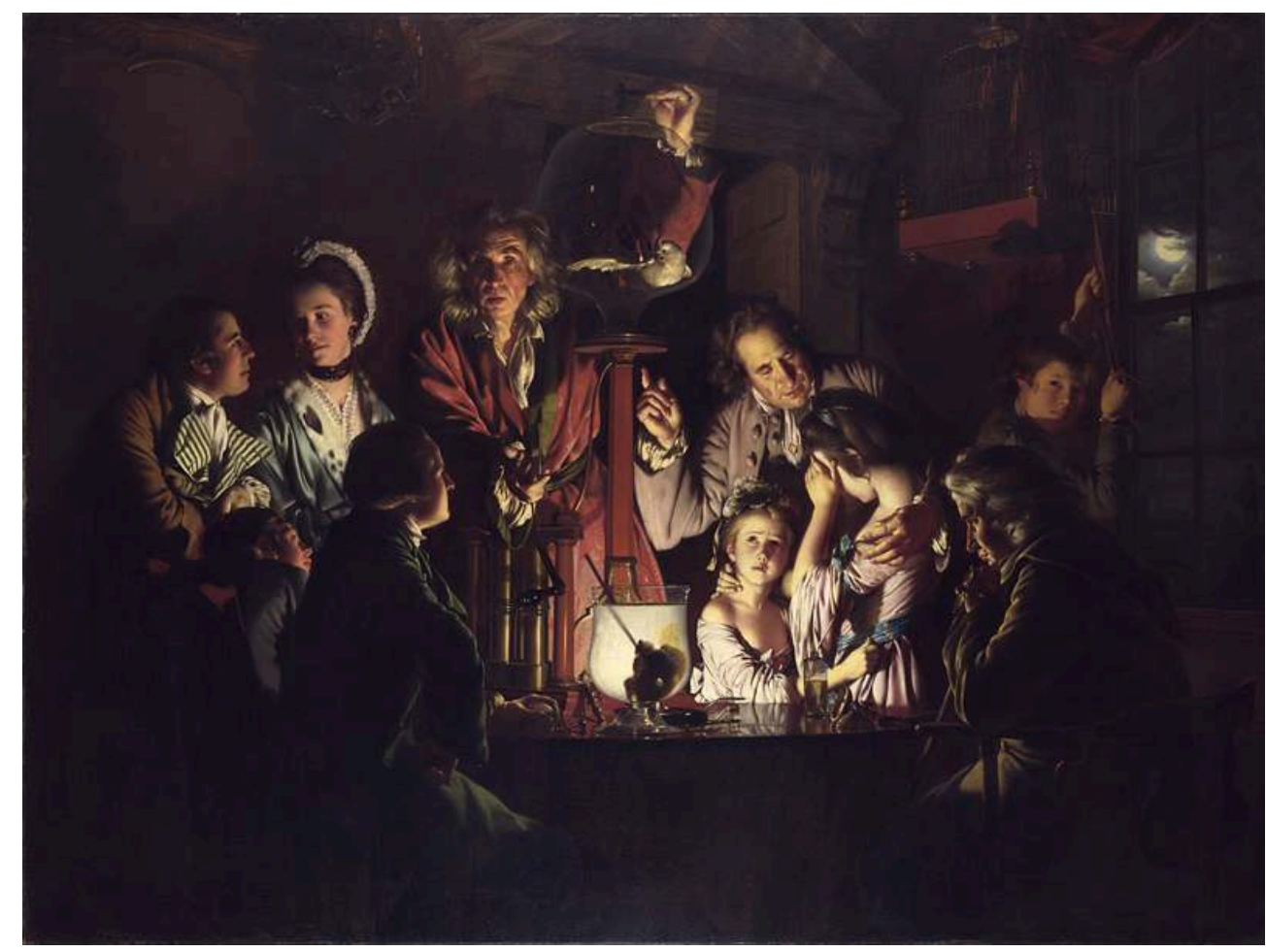

Oil on canvas, $183 \times 244 \mathrm{~cm}$, The National Gallery, London.

Source: http://www.nationalgallery.org.uk/paintings/joseph-wright-of-derby-an-experiment-on-a-birdin-the-air-pump

In spite of its rather classical manner, Wright of Derby's work is seminal in more ways than one, when it comes to examining the logic of artistic experimentation. In it, structural experimentation ties in with scientific experience. The subject of the work indeed foregrounds the triumph of visual and scientific enlightenment, as inscribed in 
modernity's epistemological agenda; but the painting's allegorical nature also captures something of the essence of modern artistic experimentation in its very link with experimental knowledge. At stake is not only modern art's "relation to experimentality in the natural sciences," (Smith 2012: 4) but precisely a ramified constellation in which enlightement and artistic reason are inscribed in content and form, as well as pictorial self-reflexiveness. In what is, after all, but a modern, enlightened vanitas, Wright of Derby anticipates on what was to be the rationale of modern art: i.e. art's capacity to reflect on its own visual economy, on its capacity to make us see, to enlighten us, while also inviting us to a a visual experience that has intrinsically to do with life and death, light and darkness, with seeing and looking away, with contemplation and fear.

5 There is, in Wright of Derby's painting, no rationality without emotion; and the emotion here painted is disturbingly akin to Kant's sublime. Deeply rooted in English empiricism, the work can only be read now as a visionary anticipation on the powerful and heuristic conjunction of experimentation with experience as it was to be explored by Romanticism and by modern art, whether one thinks of the early modernist experimentations of Claude Monet with light and atmospheric conditions, of the later experimentations of Kandinsky and his almost oxymoronic conjuring of spiritual reason, and even of Duchamp's capacity to toy with our knowledge of art in order to make us reflect on the very status of our aesthetic emotions. Deeply embedded also in the visual economy of early capitalism, the work refuses to look away from the scientific realities of its time which entailed the subjugation of nature. It seems even to flatter itself on its capacity to make us see, to bridge the gap between science, philosophy and art. Here art is anything but dis-interested. The characters in the painting are all fully engaged in the vision of the scientist's experiment on the bird and their investment is also our engagement with the action depicted and with the painter's spectacular light effects and their allegorical import. Wright of Derby's selfreflexive vision of art is thus at odds with the Kantian notion of disinterestedness propounded in his 1790 Critique of Judgment. The validity of the work lies in the here and now of visual experience which itself reflects the visual engagement in scientific experimentation and knowledge.

6 The issue of disinterestedness would return later in the guise of modern art's autonomy and that return has proved to be crucial both to the narrative of modern art and to more recent developments in artistic experimentation. As Peter Bürger reminds us in his ground-breaking essay, Theory of the Avant-garde, modern art's experimentations are premised upon its autonomy from the realm of the social: "the autonomy of art [...] permits de description of art's detachment from the context of practical life," (1984: 46) and the task of the avant-garde was, on the contrary, to bridge the gap between art and the polis, between form and context. When looking at Joseph Wright of Derby's work, one is reminded also that such an urge already drove earlier aesthetic experimentations. Indirectly anticipating on avant-garde's later questioning of art's autonomy, the work maps a visual specular space where scientific, philosophical and artistic speculation merge, where enlightenment becomes visually embodied, where sensation becomes intelligent (Bürger 1984: 1-11).

7 That process by which art bridges the gap between aesthetic experience and its material context cuts across modernity, and by material we are referring to the technical, economic, historical conditions of possibility of the work. That same process conditions both Turner's experimentation with pigments and light, and Cézanne's 
painting from nature. It is eventually reappropriated by avant-garde's programmatic undoing of artistic autonomy. With the 1920s' avant-gardes, experimentation becomes synonymous with the new, with self-reflexiveness and with art's reasserted relevance to the present:

Like the word "contemporary," the term "experimental" hovered in art discourse in many parts of the world throughout twentieth century as a synonym for avantgarde. It was favored especially when one of the arts - poetry, theatre, cinema, dance, architecture, art - "experimented" with the necessity of one of its core conventions, rendered it provisional or risked dispensing with it altogether in the interests of a higher goal (such as greater expressive power, more direct engagement with an audience, etc.). (Bürger 1984: 2)

8 My purpose here is to explore anew that zone or moment of intersection between aesthetic experimentation and material experience as offered in performance art. More specifically, in the context of Tate Modern, contemporary art's engagement with experimentation and experience will be read within the context of corporate art, one of the most blatant instances of art's constrained material conditions of visibility and of its direct involvement with the present.

\section{Experimenting / performing}

9 As several of the contributions gathered in this volume amply show, one of the forms taken by contemporary artistic experimentation has been performance. Performance best embodies that aesthetic "erosion" already identified by Theodor Adorno in "Art and the Arts" in 1966, an "erosion" thanks to which the arts become fluid, thus experimenting with their own language and putting their own generic rules and laws to the test: "The erosion of the arts is hostile to an ideal of harmony that presupposes, as the guarantee of meaning, what we might call ordered circumstances within the kinds of art. [...] It is as if the artistic genres, by denying their own firm boundaries, were gnawing away at the concept of art itself." (Adorno 2003: 384-5).

The capacity to explore the limits of one's own artistic practice has become crucial to artistic experimentation. Performance literally embodies that urge to stray and fray one's own artistic fabric, once again in order to make aesthetic experience a material and concrete one. Although the "dematerialization" of the work of art, as defined by Lucy Lippard in her 1973 essay on conceptual art, is still operative here, such dematerialisation goes with a reembodied corporeality that re-anchors the artistic experience with its material context.

11 Adorno's ambiguous geographical metaphor of art's "Verfransung" is apt in more than one sense. Straying away from one's ascribed rules and remit in order to experiment, brings art into renewed encounter with experience itself and what it means to be of the here and now, fully immersed in the present. Yet, for all its aptness, Adorno's grasp of his own spatial metaphor overlooks what it also points to, i.e. the way such artistic straying destabilises the very notion of artistic autonomy and opens the work of art to the world.

12 For many critics, experimental practices have appropriated the avant-garde's agenda and aim at reinventing art's embodied confrontation with its material conditions and with ideology at large. For Hal Foster, contemporary artists have turned ethnographers all the better to observe the shifting, critical "relation between artistic authority and 
cultural politics" (Foster 1999: 71). For Nicolas Bourriaud, such a mutation has entailed the redefinition of artistic production as a form of "postproduction" confronting the ideology of "ownership and moving toward a culture of the use of forms, a culture of constant activity of signs based on a collective ideal: sharing." (2002: 4). For Marc James Léger, in Brave New Avant-Garde, this entails a form of phasing out of art into an intermediary zone of sensory and intellectual activation that denies any categorical definition and which seems to adapt Adorno's metaphor of "straying" to the expanded field of a culture without hierarchies or limits (see also Bunzl 2014).

Performance harnesses the power of sensation and experience to artistic criticality. Even more specifically, and as many critics have noticed, ${ }^{3}$ performance, in its collective form, also entails an unhinging of the very concept of creativeness as grounded in individual inspiration and production. With collective performance, formal experimentation comes to confuse the frontiers of the individual and the collective, of production and reception. And such confusion is relevant to our present in more than one way. As Claire Bishop has noted in her essay Artificial Hells, collective or "delegated performance" seems to embrace a form of democratic program by opening itself up to the audience. Such confusion in turn takes on a critical political relevance in the sense that artistic "postproduction" can also be understood as reflecting our global system of production, with its logic of outsourcing. Delegated performance may thus also be seen to play in the hand of a system whose efficiency and economic performances heavily rely on the delegation of production and on the foregrounding of innovation and creativeness:

Through the discourse of creativity, the elitist activity of art is democratised, although today this leads to business rather than to Beuys. The dehierarchising rhetoric of artists whose projects seek to facilitate creativity ends up sounding identical to government cultural policy geared towards the twin mantras of social inclusion and creative cities. (Bishop 2012)

In many ways, collaborative performance dramatises issues and tensions that also inform other areas of collective life. As Tim Stott also remarks at length, in relation to Robert Morris' performance work, it conjures and makes tangible issues as abstract and complex as that of governance and regulation, specifically in the way collective performance must find a subtle balance between freedom and prescription (Bishop 2012).

15 As we will have the occasion to comment later, the ambiguity generated by collaborative performance has become part of the critical performativity of collaborative art, or, to return to Bishop's analysis: "Artistic practice has an element of critical negation and an ability to sustain contradiction that cannot be reconciled with the quantifiable imperative of positivist economies." (Bishop 2012: chap. 1). Collaborative performance initiates a form of creative delegation always in excess of the prescribed and predictable forms of aesthetic experience, and that even comes to allegorise part of the present cultural economy which it contributes to.

\section{Experimenting with corporate art}

But, one may wonder, what becomes of such collective practices when the critical potential of performance is itself, from the start, inscribed in the pragmatic rationale of the museum? What avails of such criticality when it is apparently harnessed to the 
complex immersive system of a museum of modern art and its incumbent economy of pleasure, reflexion and contemplation? What kind of leverage effect can collective performance still have on the overall economy of artistic experience and on the modern imperative of experience as experimentation when performance is seemingly harnessed to the complex agenda of culturtainment as exemplified in the cost-effective model of the new museums of modern art?

17 The Unilever series offers revealing insights into the complex economy of performance and experimentation as staged by one of the flagships of modern art and of the culture industry, i.e. Tate Modern. The series was launched in 2000 by Tate Modern and coincided with the museum's opening to the public. Characteristic of both the artistic turn of corporate culture and of the corporate turn of museum culture, this series crystallises the contradictions of contemporary performance as one of experimentation's privileged media; and one should remember that Tate Modern has placed performance at the centre of its expansion project, with the opening of Tate Tanks in 2012 which are specifically devoted to performance and "Art in action". ${ }^{4}$ While the series was avowedly inscribed in our commodified culture industry, it also raised disturbing questions about artistic authority and the political and symbolical economy of collective artistic experience. With the Unilever series, the museum seemed to function as an emotion plant or factory - une fabrique d'émotions - in which criticality returned to the very heart of the cultural machinery.

Choosing the Unilever series to reflect on the performative critical impact of performance may seem an odd choice, as most of the works in the series would seem to qualify as installations rather than performances. Yet most of the installations in the series also programmatically entailed the public's participation, whether it be minimal and contemplative or more immersive and active. Situated in the Turbine Hall of Tate Modern, most of the works were difficult to ignore and many had in fact to be circumnavigated before the visitors could reach either the entrance desks or the escalators leading to the exhibition spaces. 
Figure 2: Olafur Eliasson, The Weather Project, 2003

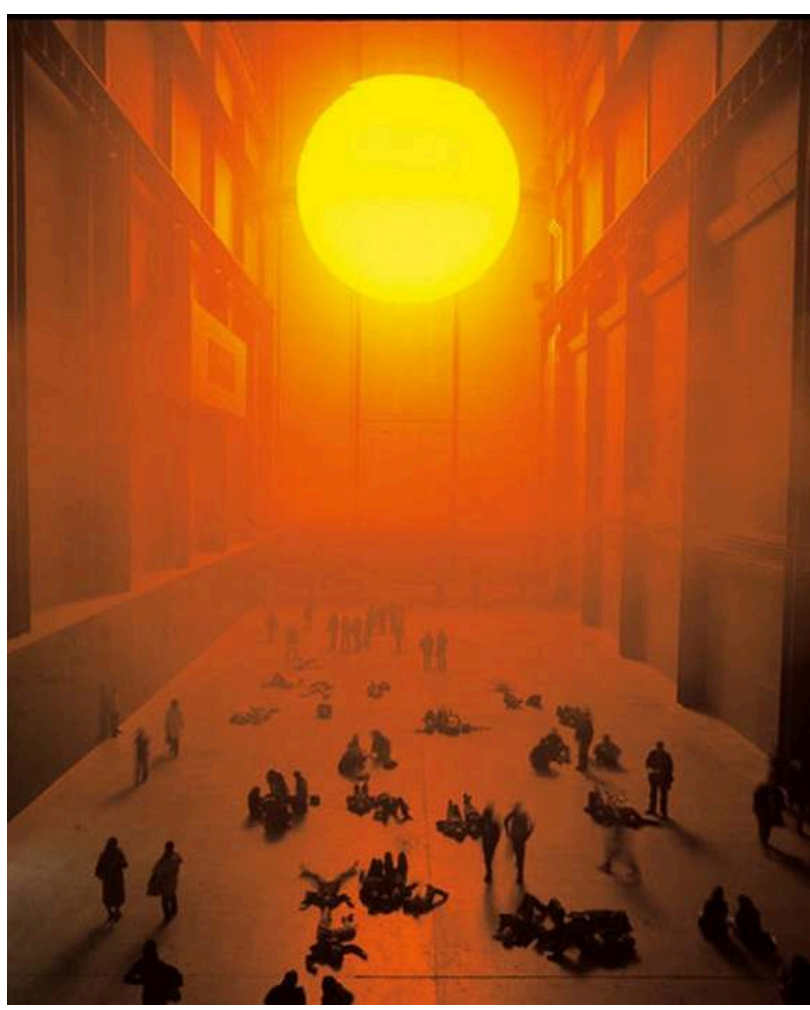

Installation view, Turbine Hall at Tate Modern.

Photo: Tate Photography (c) Olafur Eliasson. Source: https://www.royalacademy.org.uk/art-artists/ name/olafur-eliasson-hon-ra

The works in the Unilever series only existed as experience, then as the memory of that experience, as Lucy Lippard already explained about conceptual art in Six Years: The Dematerialization of the Art Object, when she stresses the short-cut produced by conceptual art from idea to practice: "The emphasis on process also led to art-as-life, life-as-art pieces" (Lippard 1973: xvi). Some of the works tapped into the vocabulary of the sublime more characteristic of American land art, with its insistence on the spiritual and the awe-inspiring; this was the case with Olafur Eliasson's 2003 Weather Project which experimented with mono frequency lighting to reconstruct an indoor sun and produce an immersive visual and atmospheric experience (Figure 2). ${ }^{5}$ More broadly, the Unilever works all involved a physical experience, itself a mixture of concept and experience, of reflexiveness and exhilaration not so distant from the experience inherent to the aesthetics of the modernist shock or of the modernist epiphany. In keeping with Tate Director Nicolas Serrota's agenda, as detailed in his 1996 Walter Neurath memorial lectures, they re-engineered the museum as a machine triggering emotion rather than interpretation. ${ }^{6}$

For many observers, the series colluded too overtly with what they denounced as the immersive and consumerist turn of museum culture. ${ }^{7}$ Yet the series' take on contemporary art's vocabulary and dialogue with its context was more subtle and paradoxical than the standard lament about the commodification of museum going would have it. The Unilever series requires us to think counter-intuitively. It requires we rethink the way the conceptual heritage works its ways through collective performance and installation art and questions the entrenched binaries opposing idea 
and sensation. As we will see, many of the works did reclaim the heritage of conceptual art. Yet they did so in order to embody that heritage, to force us to live it through. No doubt the works were sensational in more than one way: they often fully exploited the language of sensationalism, shock, surprise and even distraction, but they did so in order to force idea and emotion into a renewed dialectics.

21 So, rather than expose the supposed Disneyfication of art, rather even than simply try to reclaim the heritage of conceptual art underlying the grammar of sensation and of sensationalism that structured most of those works, we need to confront the possibility that in the Unilever series, the power of sensation is an effect of the conceptual and experimental approach to the phenomenology of art. ${ }^{8}$ As may be apparent, the monumental nature of the Turbine Hall is here of the essence. In most, if not all, of the works in the Unilever series, the conceptual, allegorical reflexion on art's vocabulary and on the emotions it produces closely depends on the exceptional, extra-ordinary nature of the Turbine Hall space. In that sense, the intensification of affect here engineered might be said to be also characteristic of what Hal Foster has defined as the "art-architecture complex" which brings together art and architecture in renewed dialogue:

Over the last fifty years, many artists opened painting, sculpture, and film to the architectural space around them, and during the same period many architects became involved in visual art. Sometimes a collaboration, sometimes a competition, this encounter is now a primary site of image-making and space-shaping in our cultural economy (Foster 2011: vii). ${ }^{9}$

\section{Opening up}

We would like to take two concluding examples of the paradoxical criticality of the works produced as part of the Unilever series: Doris Salcedo's 2007-2008 Shibboleth and Tino Sehgal's 2012 These Associations.

Columbian sculptor Doris Salcedo's 2007-2008 commission, Shibboleth, was exemplary of the dialectics of concept and sensation foregrounded earlier. Consisting of a 167-metrelong forking crack opening up in the concrete floor of the Turbine hall, Shibboleth pushed back the limits of installation art - did it still qualify as an installation? -, and produced a form of embodied narrative by which we came to experience the work's conceptual program (Figure 3). 
Figure 3: Doris Salcedo, Shibboleth I, 2007. Tate Modern

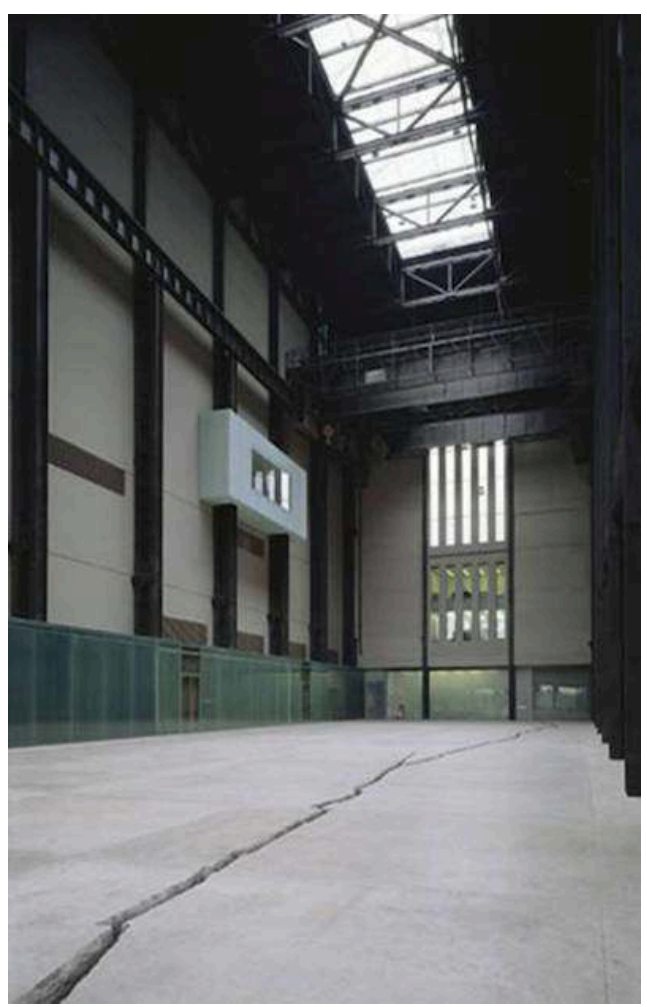

(c) Doris Salcedo. Source: http://www.tate.org.uk/art/artists/doris-salcedo-2695 Taking after the Bible's allegorical logic, it is a branch from which potential meanings branch out endlessly and is also a powerful discriminant in more ways than one. It literally divided the museum space, and the visitors were compelled to act out the division when they stepped across the fracture. Stepping across the rift made the public suddenly aware of a space they usually walked through without paying much attention to its function and nature. The rift thus functioned as a reflexive trigger making the space and its cultural function suddenly tangible. The natural aspect of the rift - it is reminiscent of the great geological rifts - foregrounded the cultural space of the gallery in an empirical way that literally embodied and made us reflect upon the conceptual/cultural/physical/political nature of the experience entailed in a visit to the temple of culture, i.e. the museum. It dissected the space of the gallery, made it tangible at last, functioning like a hyperbolical post-object installation. At the same time it moved beyond this primary acception of the term to act against the concept and addressed our bodies in space, the space of the gallery, made suddenly unfamiliar again.

The reference to the Shibboleth may also be to Derrida's own take on the Biblical Shibboleth. ${ }^{11}$ With Derrida, we could argue that Salcedo's shibboleth was a trial, a trial which fully addressed and engaged the language of the tribe in its exclusive and inclusive power. The rift speaks out in the language of the tribe, of those who are fully museum-literate and can understand, discriminate the parable behind the empirical experience. Yet, its powerfully physical address also sublated the exclusion. Its conceptual and formal references may have remained concealed from many a visitor, yet it addressed us all, and thus an inchoate, immediate form of address literally took 
place, just as the poem takes place in us in its address: "The poem speaks, even should none of its references be intelligible, none other than the Other, the one to whom it addresses itself" (Derrida 1994: 35).

Salcedo's Shibboleth activated a form of reflexive experience, which also touches upon global issues of spatial demarcation and frontiers with their incumbent experience of loss and fracturing..$^{12}$ A recent exhibition of Salcedo's work at Harvard Art Museums logically elaborated on the theme of mourning to understand works that both metaphorise and materialise contemporary experiences of loss. In her keynote lecture to the symposium organised with the exhibition, Judith Butler chose to take Salcedo's work as precisely relating to the necessity to "activat[e] the performative dimension of public grieving"13 Thus experimentation with the language of installation art and performance - in their most ramified and complex economy - may be said to produce an allegorical, and yet embodied critical experience with ramifications extending far beyond the remit of Shibboleth while being already implicit in it.

The last commission in the Unilever series offered just as complex an instance of the dialectics of concept and sensation that rules contemporary installation and performance art. Sehgal's These Associations offered a disturbing recapitulation of the questions raised by many of the works commissioned for the series: how can art reclaim the museum space for aesthetic experience? How can that process also reclaim the language of experimentation and avant-garde within the remit of the globalised museum economy? Just as importantly for the present volume and for my discussion of the criticality of aesthetic experience, what kind of critical leverage may experimentations with aesthetic participation and reception still achieve in our global age of short-lived extasies?

If Tino Sehgal's These Associations was both highly conceptual and highly embodied, it was all the better to harness the language of participatory art to a criticism of authority and collectiveness. Sehgal's participatory performance evinced all the characteristics of participatory art. It relied both on "delegated performance," on "multiple authorship" to resort to Boris Groys' term (2007: chap. 7), ${ }^{14}$ as well as on the redefinition of production as post-production in Nicolas Bourriaud's terms already mentioned. For These Associations Sehgal brought together a group of participants alternating scripted collective movements and more intimate dialogues with visitors chosen at random and during which the performers revealed private memories. The performance was both neatly premeditated and unpredictable. The movements were choreographed and timed, yet both the choreographed moments and the dialogues needed to adapt to the shifting presence of the visitors.

Because of its collective nature, These Associations lends itself to renewed allegorical readings of the process of delegated labour. Sehgal's agenda offers an embodied reflexion on "the ethics and aesthetics of contemporary labour," to resort to Bishop's analysis of delegated performance. Especially in so far as it may seem to stage the process of outsourcing, delegated performance may seem to mimic the "managerial changes in the economy at large" (Bishop 2012). But such mimicry is no endorsement. Engaging with the spectacular machine of the museum made for a collective experimentation which brought into question the economics of emotion..$^{15}$ Sehgal's experimentation with the language of performance addressed the sense of collectiveness in complex, once again, ramified ways. The questions raised by These Associations were many: who, for instance, retained the authorship of such a collective 
achievement? A question which, in turn, reflected back both on the globalisation and mutation of the productive economy and the necessity to think the effects of such changes through. How did such an experimentation tie in, for instance, not so much with the logic of outsourcing but with other collaborative experimentations in our contemporary world? How did it reflect, for instance, on the new collaborative economy of the creative commons explored by Jeremy Rifkin in Zero Marginal cost Society (2014)?

These Associations allegorised, scripted, staged these questions in order to address our lived-in present through the language of experimentation. Performance allowed these questions to be embodied and lived through, at the heart of the museum engine, in the turbine of our global culture industry, where every experience seems doomed to be commodified and turned into marketable goods necessary to produce more aesthetic experience. ${ }^{16}$

In its programmatic collusion with the global machinery of marketed culture, the Unilever series occupied an aporetic zone, where the paradoxes of art were turned into lived experience. Paradoxically following in the distant footsteps of Wright of Derby's enlightened yet incarnate reflexion on the power of vision and representation, following also in the footsteps of the great avant-garde, the Unilever series artists addressed us from the turbine of art, to move beyond the fracture of art and society and address the unfathomable paradoxes of what may be defined as the new artistic collaborative commons.

\section{BIBLIOGRAPHY}

Adorno, Theodor. "Art and the Arts," Can One Live After Auschwitz? A Philosophical Reader. Rolf Tiedemann, ed. Redwood City: Stanford UP, 2003.

Adorno, Theodor. L'art et les arts. Jean Lauxerois and Peter Szendy, trans. Paris: Desclée de Brouwer, 2002.

Benjamin, Walter. Paris Capitale du XIXe siècle. Rolf Tiedemann, ed. Paris: Les Éditions du Cerf, 1989.

Benjamin, Walter. "Theses on the Philosophy of History." Illuminations. Hannah Arendt, ed. London: Pimlico, 1999. 253-264.

Benjamin, Walter. Baudelaire. Giorgio Agamben, Barbare Chitussi and Clemens-Carl Härle, eds. Paris: La fabrique, 2013.

Bishop, Claire. Artificial Hells. Participatory Art and the Politics of Spectatorship. London: Verso, 2012.

Bourriaud, Nicolas. "Preface to the Second Edition," Postproduction. Culture as Screenplay: How Art Reprograms the World. New York: Lukas \& Sternberg, 2002. 4. http://faculty.georgetown.edu/ irvinem/theory/Bourriaud-Postproduction2.pdf

Broqua, Vincent. À partir de rien. Esthétique, poétique, politique de l'infime. Paris: Michel Houdiard, 2013a. 
Broqua, Vincent. Expériences de l'expérimental, Habilitation à diriger des recherches, document de synthèse, Université Paris Diderot, 2013b (unpublished).

Bunzl, Matti. In Search of a Lost Avant-Garde. An Anthropologist Investigates the Contemporary Museum. Chicago: The U. of Chicago P., 2014.

Bürger, Peter. Theory of the Avant-Garde (1974). Trans. By Michael Shaw. Minneapolis: U. of Minnesota P., 1984.

Danto, Arthur. The Visual Arts in Post-Historical Perspective. Berkeley: U. of California P., 1992.

Danto, Arthur. After the End of Art. Contemporary Art and the Pale of History. Princeton: Princeton UP, 1997.

Davidts, Wouter. “The Vast and the Void. On Tate Modern's Turbine Hall and 'The Unilever Series'," Footprint. Delft Architecture Theory Journal, 1 (Autumn 2007): 77-92. DOI: 10.7480/footprint. 1.1 .669

Derrida, Jacques. Schibboleth pour Paul Celan. Paris: Galilée, 2003.

Derrida, Jacques. "Shibboleth [sic] For Paul Celan," in Aris Fioretos, ed. Word Traces: Readings of Paul Celan. Baltimore: The Johns Hopkins UP, 1994. 3-74.

Foster, Hal. "The Artist as Ethnographer," The Return of the Real. Cambridge [Mass.]: MIT Press, 1999. 171.

Foster, Hal. The Art-Architecture Complex, London: Verso, 2011.

Groys, Boris. Art Power. Cambridge [Mass.]: the MIT Press, 2008.

Kelly, Michael, A Hunger for Aesthetics. Enacting the Demands of Art. New York: Columbia UP, 2012.

Kester, Grant H. The One and the Many: Contemporary Collaborative Art in a Global Context. Durham [GA]: Duke UP, 2011.

Kwon, Miwon. One Place After Another: Site-specificity and Locational Identity. Cambridge [Mass.]: MIT Press, 2002.

Léger, Marc James. Brave New Avant Garde. Essays on Contemporary Art and Politics. Aldershot: Zero Books, 2014.

Lippard, Lucy. Six Years: The Dematerialization of the Art Object from 1966 to 1972. New York: Praeger, 1973.

Rifkin, Jeremy. The Zero Marginal Cost Society. London: Palgrave, 2014.

Serrota, Nicolas. Emotion or Interpretation. The Dilemna of Museums of Modern Art. London: Thames \& Hudson, 2000.

Stott, Tim. Play and Participation in Contemporary Arts Practices. London: Routledge, 2015.

Smith, Terry. "Experimentality: Theories and Practices," Studies in Material Thinking, vol. 8, "Experimental Art," May 2012. https://www.materialthinking.org/papers/89

Thompson N., ed., Living as Form-Socially Engaged Art from 1991-2011. Cambridge [Mass.]: MIT Press, 2012.

Trentini, Bruno. "Peut-on faire une esthétique incarnée du jugement réfléchissant?" Naturaliser l'esthétique? Questions et enjeux d'un programme philosophique. Jacques Morizot, ed. Rennes: Presses Universitaires de Rennes, 2014. 201-215. 
Wilson, Siona. Art Labor, Sex Politics. Feminist Effects in 1970s British Art and Performance.

Minneapolis: U. of Minnesota P., 2015.

\section{NOTES}

1. See also Broqua (2013a). I am aware that translating "étoilement" as "constellation" tinges the argument with deliberately Benjaminian overtones, but it seems to me that Benjamin's constellation hankers after a metaphor that might capture something of the experimental nature of thought processes that are both sensitive and allegorical. In his entry devoted to the notion of "Constellation" of the recently discovered notes towards his essay on Baudelaire, Benjamin mentions the "Constellation of sensitive temperament and allegorical intelligence," (Benjamin 2013: 628). One should also insist on how crucial to a historical approach to art Benjamin's constellation proves to be, since in his $18^{\text {th }}$ Thesis on the Philosophy of History as well as in the Book of Passages, he defines the arrested dialectic produced by a constellation as the juncture of past and present (Benjamin 1989: 478-9; 1999: 255).

2. One should point out the ambiguity of Adorno's original metaphor: the term used

"Verfransung" connotes both a geographical "straying" and a material "fraying" of the boundaries or hems of the arts. The French translation, probably under the unavowed influence of Barthes' conception of the text as texture, opts for "effrangement" ("fraying"), see Adorno (2002: 43-74).

3. See, for instance, Wilson (2015); Thompson (2012); Kester (2011); in relation to site-specificity: Kwon (2002).

4. This was the title of the inaugural program of Tate's tanks in 2013. The slogan can still be found in a picture of the Tank Foyer: http://www.tate.org.uk/visit/tate-modern/tanks.

5. Olafur Eliasson, The Weather Project, 2003. Monofrequency lights, projection foil, haze machines, mirror foil, aluminium, and scaffolding, $26.7 \mathrm{~m} \mathrm{x} 22.3 \mathrm{~m}$ x $155.4 \mathrm{~m}$. The museum's website explanatory note interestingly refers back to the Enlightenment and quotes Samuel Johnson: "The subject of the weather has long shaped the content of everyday conversation. The eighteenth-century writer Samuel Johnson famously remarked 'It is commonly observed, that when two Englishmen meet, their first talk is of the weather; they are in haste to tell each other, what each must already know, that it is hot or cold, bright or cloudy, windy or calm.' In The Weather Project, the fourth in the annual Unilever Series of commissions for the Turbine Hall, Olafur Eliasson takes this ubiquitous subject as the basis for exploring ideas about experience, mediation and representation." http://www.tate.org.uk/whats-on/tate-modern/exhibition/ unilever-series/unilever-series-olafur-eliasson-weather-project-0 .

6. The lectures were given in the runner up to the Tate launch and published in paperback by Thames \& Hudson in 2000, the year of Tate's opening (Serrota 2000).

7. For a panorama of the various takes on Tate Modern more broadly, see the contributions to the round table "Tate Modern" in October. As expected, art critic Julian Stallabrass was highly critical of Tate Modern's de-hierarchising agenda: "what the Tate displays is much more the postmodern smorgasbord. It's Arthur Danto's idea that we've come to the end of the narrative and we can now just play happily ever after within this field of various contents, which are wonderful because they are various, and we can just mix and match as we like." (Stallabrass 2001: 9).

8. A similar suggestion has been made by Bruno Trentini: "Peut-on faire une esthétique incarnée du jugement réfléchissant?" In this chapter Trentini turns, for his part, to the entanglement of cognition and sensation characteristic of the aesthetic experience. In his defense of an "embodied aesthetics" he analyses the aesthetic relation as pertaining to the cognitive impulse and as the embodiment of that impulse, a dialectics which informs the self-reflexive nature of 
artistic experience as thinking emotion: "Cet acte réfléchissant, dont l'émotion dépend avant tout de l'élan cognitif lui-même dépendant des singularités de l'œuvre, s'accompagne d'un mouvement projectif au sens où l'œuvre est considérée comme cause de l'émotion éprouvée." (in Morizot 2014: 214).

9. On the impact and economy of size in the Unilever series, see Davidts (2007).

10. The term "Shibboleth" denotes a stream or an ear of corn. In Judges 12.6, the correct pronunciation of the word Shibboleth is a matter of life and death and distinguishes the two sister and yet enemy tribes descending from Ephraïm and Manasseh.

11. See Jacques Derrida's lecture on Paul Celan, published under the title Schibboleth pour Paul Celan (2003), and itself a homage to Celan's poem "Shibboleth", published in the collection Von Schwelle Zu Schwelle (From Threshold to Threshold) in 1955, in which Celan accounts for the radical condition of existing on the threshold. We will not have the time to analyse the importance of Derrida's "misprint" of Celan Shibboleth as Schibboleth, but it is of course crucial to his reading of the poem's address.

12. For such a reading of the work, see Kelly 2012: chapter 4, "The Salcedo Effect".

13. "Doris Salcedo: The Materiality of Mourning," Harvard Art Museums, November 4, 2016-April

9, 2017: https://www.harvardartmuseums.org/visit/exhibitions/5201/doris-salcedo-themateriality-of-mourning. For Judith Butler's keynote, see https://www.youtube.com/watch? $\mathrm{v}=909$ _ZP2Z7aI.

14. Groys focuses specifically on installation art which he considers to exemplify the redefinition of the traditional tasks of the artist, the curator and the spectator.

15. This does not mean that non-delegated performance may not achieve a similar level of criticality. Marina Abramovic's 2014512 hours performed in the Serpentine Gallery is a good case in point. For this performance, she invited members of the audience to come and stand in front of a blank wall while whispering in their ears to think about the present. By entailing a form of productive dissemination of aesthetic emotion, her performance also reflected on issues of authorship, and power and pushed back the boundaries of the private and the collective.

16. See for instance the rhetoric of sensation and entertainment used in the presentation of the Tate Modern extension project: "This new development will transform Tate Modern. An iconic new building will be added at the south of the existing gallery. It will create more spaces for displaying the collection, performance and installation art and learning, all allowing visitors to engage more deeply with art, as well as creating more social spaces for visitors to unwind and relax in the gallery." http://www.tate.org.uk/about-us/projects/tate-modern-project. Switch House - now the Blavatnik Building, after one of the most influential patrons of Tate, Len Blavatnik - was inaugurated on June 17, 2016.

\section{ABSTRACTS}

Artistic experimentation, as well as the concepts elaborated to define it, have undergone considerable changes since the age of the avant-gardes and yet experimentation still retains some of its critical purchase. The present article focuses on recent experimentations in the field of installation and performance art and on the way these works may enlighten us on the kind of critical leverage offered by aesthetic experimentation in its complex and often conflicted relation to our contemporary sensorium. Taking the case of some of the most prominent installations and performances commissioned by Tate Modern as part of the Unilever Series 
(2000-2012), we intend to understand how the criticality of experimentation as imagined by the great avant-gardes has been queered and reinvented by artists who work within the regime of the spectacular while remaining faithful to the incisive spirit of experimentation. Our first intention is to explore the empiricist legacy of experimentation, by returning to the semantic pairing of scientific and artistic experimentation, as evidenced, for example, in Joseph Wright of Derby's great oil: An Experiment on a Bird in an Air Pump (1768). Placing the likes of Doris Salcedo's Shibboleth (2008) and Tino Sehgal's These Associations (2012) in a long historical and critical perspective, we intend to highlight a still relatively under-explored aspect of experimentation: that of corporeality and sensation in their relation to critical knowledge. Taking experimentation to rely on a subtle tension between sensation and intellection or between experience and concept, we try to show how contemporary experimentation reinvents such a tension. Placed at the very heart of the museum machine and of its economy of attraction, the works in the Unilever Series foregrounded the economy of sensation often harnessing the sensational to a complex critical stance. Working both with and against the sensation regime imposed by the culture industry, these works elaborated complex experiential allegories in which the visitor's experience worked towards differential modes of being. More specifically even, it was, we argue, their collective logic that gave us to grasp our current regime of visibility and experience, at the juncture of the private and the public, of sensation and corporate culture.

L'expérimentation dans l'art, tout comme les concepts élaborés pour la définir, ont connu de très profonds changements depuis l'ère des grandes avant-gardes et pourtant l'expérimentation conserve une incontestable puissance de décentrement critique. Cet article se tourne vers des expérimentations récentes dans le champ de l'installation et de la performance, et s'intéresse à la manière dont elles nous éclairent sur la relation complexe et souvent conflictuelle que l'art entretient avec notre sensorium. Prenant pour exemples certaines des créations qui virent le jour dans le cadre de l'Unilever Series, commissionnée par Tate Modern entre 2000 et 2012, nous souhaitons comprendre comment la visée critique de l'expérimentation telle que définie par les avant-gardes a été repensée par des artistes qui travaillent de l'intérieur du régime spectaculaire de l'art, tout en restant fidèles à la volonté incisive de l'expérimentation. Notre intention est tout d'abord d'explorer l'héritage empiriste de l'expérimentation, en revenant sur l'association qui lie sémantiquement les régimes scientifique et artistique de l'expérimentation, telle qu'elle est donnée à voir, par exemple, dans l'huile de Joseph Wright of Derby, An Experiment on a Bird in an Air Pump (1768). Lisant des œuvres telles que Shibboleth de Doris Salcedo (2008) ou These Associations de Tino Sehgal (2012) dans une perspective historique et théorique longue, nous visons à comprendre un aspect encore peu exploré de l'expérimentation: le lien entre la sensation ou la corporéité et l'élaboration d'un savoir critique. L'expérimentation est ici perçue comme fondée sur une tension subtile entre sensation et intellection, ou encore entre expérience et conceptualisation, et nous souhaitons montrer comment l'expérimentation contemporaine tente de réinventer cette tension. Placées au centre de la machine muséale et de son économie de l'attraction, les œuvres de l'Unilever Series donnaient à voir l'économie de la sensation et mettaient le sensationnel au service d'une vision critique complexe. Travaillant à la fois avec et contre le régime de sensation imaginée par l'industrie culturelle, ces œuvres élaborèrent de complexes allégories dans lesquelles l'expérience du visiteur induisait des régimes d'expérience différentiels. C'est plus spécifiquement encore leur logique collective qui nous permettait de comprendre les régimes de visibilité et d'expérience actuels, tels qu'ils travaillent à la jonction du privé et du public, de la sensation et de la culture capitaliste. 


\section{INDEX}

Mots-clés: art expérimental, art contemporain, performance, Tate Modern, Unilever Series, Salcedo Doris, Sehgal Tino

Keywords: experimental art, contemporary art, installation art, performance art, Tate Modern, Unilever Series, Salcedo Doris, Sehgal Tino

\section{AUTHOR}

\section{CATHERINE BERNARD}

Catherine Bernard is Professor of English literature and art history at Paris Diderot University, UMR 8225 (Laboratoire de Recherche sur les Cultures Anglophones). Her research hinges on the history and the politics of forms and aesthetics, from Modernism to contemporary aesthetics. She has published extensively on modernist and contemporary visual culture and art (from the Bloomsbury group, to Andy Warhol, David Hockney, but also Gillian Wearing, Rachel Whiteread or Mark Wallinger). Among her most recent publications in that field, one may mention: "Christopher Nolan's Inception: Spectacular Speculations," Screen, Martine Beugnet et Jane Sillars (eds.), "The Reflexive Turn: Mediating and Remediating Hollywood," n58/2, Spring 2017, https://academic.oup.com/screen/article-abstract/58/2/229/3866484?redirectedFrom=fulltext; "La vielle dame et la preneuse de son : (micro)-utopies d'un art de l'ordinaire," Polysèmes, AnneLaure Fortin (ed.), "L’art intempestif - La démesure du temps," n¹7, Spring 2017, http:// journals.openedition.org/polysemes/1794; “Âmes sensibles s'abstenir : violence à / de l'art contemporain. À propos de Gillian Wearing, Damien Hirst, les frères Chapman \& co.," Sillages critiques, Marc Amfreville, Aloysia Rousseau et Armelle Sabatier (eds.), "Écriture de la violence," $\mathrm{n}^{\circ} 22,2017$, https://sillagescritiques.revues.org/4846; as well as the following chapters: "Modernity's Sylvan Subjectivity, from Gainsborough to Gallaccio," in Julian Wolfreys (ed.), New Critical Thinking. Criticism to Come, Edimbourg: Edinburgh UP, 2017, pp. 36-49; "Rethinking Originality / Making Us See: Contemporary Art's Strategic Transpositions," in Sonya Stephens (ed.) Translation and the Arts in Modern France (ouvrage en l'honneur du Professeur Rosemary Lloyd), Bloomington: University of Indiana Press, 2017, pp. 237-247. Her research has also focused both on Modernist literature and on contemporary English fiction (Graham Swift, Martin Amis...). She is the author of critical editions and translations into French of Flush (Paris: Gallimard, coll. La Pléiade, 2012) and of a selection of Virginia Woolf's essays (Essais choisis, Paris: Gallimard, 2015). She has also edited several volumes of Études britanniques contemporaines, among which: "State of Britain", Études britanniques contemporaines, n49, 2015, http://ebc.revues.org/2603, as well as "Reassessing Literary Commitment (Anew)", "Commitment / L'engagement", Études britanniques contemporaines, $\mathrm{n}^{\circ} 50,2016$. http://ebc.revues.org/3074. She is currently working towards a monograph on the body politic of contemporary British fiction and visual arts to be published in 2018 with the Presses de l'Université Paris-Sorbonne. Contact: catherine.bernard[at]univ-paris-diderot.fr. 